\title{
ANALYSIS OF PHOTOKERATITIS-RELATED RISK FACTORS IN WELDERS OF PT. PAL INDONESIA (PERSERO) SURABAYA
}

\author{
Mandy Muskita ${ }^{1}$, Tri Martiana ${ }^{2,}$ Oedojo Soedirham ${ }^{3}$ \\ ${ }^{I}$ Magister of Occupational Health and Safety, Airlangga University, Surabaya, Indonesia \\ ${ }^{2}$ Departement of Occupational Health and Safety Public Health, Airlangga University, Surabaya, Indonesia \\ ${ }^{3}$ Health Promotion and Behavioural Science Departement, Faculty of Public Health, Airlangga University, Surabaya, \\ Indonesia
}

\begin{abstract}
During welding activities, there are eye-related electromagnetic light and ultraviolet is one of them. After 2 to 10 hours of ultraviolet exposure, a welder will complain of pain, sandy feeling, and other eye-related complaints. A disease caused by ultraviolet derived from welding activities is called photokeratitis. The purpose of the present study was to analyze photokeratitisrelated risk factors in welders. This study was a quantitative analytic survey using a cross-sectional design involving 50 respondents. Results of fluorescein test of 50 welders showed that 29 welders were photokeratitis-positive. Logistic regression test of respondents with UV exposure intensity of $0.3 \mathrm{~mW} / \mathrm{cm}^{2}$ showed that those respondents had 5.55 times higher risk of developing photokeratitis than respondents exposed to an UV intensity of less than $0.3 \mathrm{~mW} / \mathrm{cm}^{2}$. Respondents aged 41 years and above had 7.09 times higher risk of developing photokeratitis than respondents aged below 41 years. Respondents rarely taking vitamin A had 15.87 times higher risk of developing photokeratitis than those frequently taking vitamin A. Respondents always experiencing eye complaints had 12.82 times higher risk of experiencing photokeratitis than those never had eye-related complaints. Respondents occasionally using personal protective equipment had 29.41 times higher risk of developing photokeratitis than those always using personal protective equipment. Respondents with the length of exposure of more than 8 hours had 4.87 times higher risk of developing photokeratitis than those with the length of exposure of less than 8 hours. The variable representing the most dominant risk factor for photokeratitis respondents was the use of personal protective equipment with 29.41 times higher risk than other independent variables.
\end{abstract}

Keywords: welders, ultraviolet radiation, photokeratitis, general engineering

\section{INTRODUCTION}

Regulation of the Minister of Manpower and Transmigration No:Per.03/ MEN/1982 on Health Services Labor chapter 1 states of health care is the health of the business carried out with the aim: to provide assistance to workers in the adjustment of physical, mental, work with power labor, protecting workers against any health problems arising from employment or work environment.

One type of work that has the potential for disease due to the employment relationship is at welding processing. The welding process is one of the largest sources of artificial ultraviolet light. Optical radiation physicist, Lyon (1977) conducted a study that during welding activities exist electromagnetic rays that give effect to the eyes and one of them is ultraviolet light. After 2-10 hours of ultraviolet exposure, a welding workers will feel the complaint is pain in the eyes, the eyes speckle, possessed eyes like sand (sandy feeling), and other eye complaints. Diseases that may arise due to the ultraviolet rays from the welding process include photokeratitis.

The scope of this study is the use of welding techniques in the construction of ships, rapid pipe, pipeline, steel frame and so on PT. PAL Indonesia (Persero) with the amount of welding work using an electric welding roughly a third of all jobs. The welding process is one of the largest sources of artificial ultraviolet light. Preliminary studies conducted by distributing questionnaires to welding workers (welders) in the Division of General Engineering (General Engineering) conducting non-vessel production process. The results of the questionnaire that was distributed to 60 people, 36 of them said workers had more than two eyes among other eye complaints such as sandy feeling, lots of tears, photophobia, eyes stinging and blurred vision, which is thought to be due to exposure photokeratitis ultraviolet light, while 24 others have only one complaint and some are not experiencing any complaints.

\section{MATTER AND METHOD}

This study uses an observational study with cross-sectional study design to analyze the risk factors associated with the occurrence of photokeratitis the welder who perform nonvessel welding work in PT. PAL Indonesia (Persero).

The population of this study was all employees of the welder in the Division of General Engineering (General Engineering) PT. PAL Indonesia (Persero), as many as 50 people. The sampling technique was not performed in this study due to be carried out research on all members of the population, namely the welder who was 50 people. 
Techniques of Data collection was using interview techniques with questionnaires, observations with the checklist, the measurement of the intensity of ultraviolet radiation and eye health examination. Bivariate analysis using the test as well as the relationship of the risk while multivariate analysis using logistic regression. The independent variables in this study are the characteristics of respondents (age, the pattern of consumption of vitamin A, eye complaints, use of PPE), the characteristics of the respondents work includes working lives, long exposure, the intensity of ultraviolet radiation exposure. The dependent variable is photokeratitis.

\section{RESULT}

Table 1 shows the risk factors between the characteristics of the respondents with the photokeratitis. Variable use of personal protective equipment of the risk respondents who sometimes use PPE at 6.955 times than respondents who are constantly using PPE.

Respondents over the age of 41 years at risk of photokeratitis that is equal to 5.231 times than respondents aged less than 41 years. Higher risk of respondents who always had an eye for the photokeratitis complaints of 5.111 times than respondents who have never experienced eye complaints.

Respondents who rarely consume vitamin A higher risk for photokeratitis by 5.107 times compared with respondents who always consume vitamin A.

Overall variable in the characteristics of the respondents, the most dominant risk factor for respondents to experience photokeratitis is the variable use of personal protective equipment with a value of OR is 6.955 .

Table 1 Relationship Test and Odd Ratio between Characteristics of Respondents with photokeratitis in welders of PT. PAL Indonesia (Persero) Surabaya, 2014

\begin{tabular}{|c|c|c|c|c|c|c|c|c|}
\hline \multirow{3}{*}{\multicolumn{2}{|c|}{$\begin{array}{l}\text { Independent Variable } \\
\text { ( Responden Characteristic) }\end{array}$}} & \multicolumn{6}{|c|}{ Dependent Variable (Photokeratitis) } & \multirow{3}{*}{$\mathbf{O R}$} \\
\hline & & \multicolumn{2}{|l|}{$(+)$} & \multicolumn{2}{|l|}{$(-)$} & \multirow{2}{*}{$\mathbf{N}$} & \multirow{2}{*}{$\%$} & \\
\hline & & $\mathbf{n}$ & $\%$ & $\mathbf{n}$ & $\%$ & & & \\
\hline \multirow{2}{*}{ Age } & $\begin{array}{l}>41 \\
\text { Years }\end{array}$ & 16 & 80 & 4 & 20 & 20 & 100 & \multirow[t]{3}{*}{5,231} \\
\hline & $\begin{array}{l}\leq 41 \\
\text { Years }\end{array}$ & 13 & 43,33 & 17 & 56,67 & 30 & 100 & \\
\hline \multicolumn{2}{|l|}{ Total } & 29 & 58 & 21 & 42 & $\mathbf{5 0}$ & 100 & \\
\hline \multirow[t]{2}{*}{ Complaint Eyes } & Always & 23 & 71,88 & 9 & 28,12 & 32 & 100 & \multirow[b]{3}{*}{5,111} \\
\hline & Never & 6 & 33,33 & 12 & 66,67 & 18 & 100 & \\
\hline \multicolumn{2}{|l|}{ Total } & 29 & 58 & 21 & 42 & 50 & 100 & \\
\hline \multirow{2}{*}{$\begin{array}{l}\text { Consumption of } \\
\text { Vitamin A Rarely Often }\end{array}$} & Rarely & 22 & 73,33 & 8 & 26,67 & 30 & 100 & \multirow{3}{*}{5,107} \\
\hline & Often & 7 & 35 & 13 & 65 & 20 & 100 & \\
\hline \multicolumn{2}{|l|}{ Total } & 29 & 58 & 21 & 42 & 50 & 100 & \\
\hline \multirow[t]{2}{*}{ The Use of PPE } & Rarely & 18 & 81,82 & 4 & 18,18 & 22 & 100 & \multirow{3}{*}{6,955} \\
\hline & Always & 11 & 50 & 17 & 60,71 & 28 & 100 & \\
\hline \multicolumn{2}{|l|}{ Total } & 29 & 58 & 21 & 42 & 50 & 100 & \\
\hline
\end{tabular}

Table 2 shows the relationship between the characteristics and substantial risk that respondents work includes long exposure and intensity of exposure to UV radiation. Higher risk for respondents who are exposed to more than 8 hours to experience photokeratitis at 4.266 times the experience photokeratitis than respondents who are exposed to less than 8 hours.
Variable intensity of UV radiation exposure measured in this study after analyzed for photokeratitis higher risk of exposure to UV radiation intensity variable that is equal to 4.266 times for each increase of $0.3 \mathrm{~mW} / \mathrm{cm} 2$.

Overall variables in job characteristics, there is no predominant risk factor for respondents to experience photokeratitis because it has the same OR value, namely 4.266 . 
Table 2 Relationship Test and Odd Ratio between the characteristics of the job with the occurrence of photokeratitis in welders of PT. PAL Indonesia (Persero) Surabaya, 2014.

\begin{tabular}{|c|c|c|c|c|c|c|c|c|}
\hline \multirow{3}{*}{\multicolumn{2}{|c|}{$\begin{array}{l}\text { Independent Variable } \\
\text { (Respondent Characteristic) }\end{array}$}} & \multicolumn{6}{|c|}{ Dependent Variable (Photokeratitis) } & \multirow{3}{*}{ OR } \\
\hline & & \multicolumn{2}{|c|}{$(+)$} & \multicolumn{2}{|l|}{$(-)$} & \multirow{2}{*}{$\mathbf{N}$} & \multirow[b]{2}{*}{$\%$} & \\
\hline & & $\mathrm{n}$ & $\%$ & $\mathrm{n}$ & $\%$ & & & \\
\hline \multirow{2}{*}{ Intensity of exposure } & $>8$ Hours & 21 & 72,41 & 8 & 27,59 & 29 & 100 & \multirow{3}{*}{4,266} \\
\hline & $\leq 8$ Hours & 8 & 38,10 & 13 & 61,90 & 21 & 100 & \\
\hline \multicolumn{2}{|l|}{ Total } & 29 & 58 & 21 & 42 & 50 & 100 & \\
\hline \multirow{2}{*}{$\begin{array}{l}\text { intensity of } \mathrm{UV} \\
\text { radiation exposure }\end{array}$} & $>0,3 \mathrm{~mW} / \mathrm{cm}^{2}$ & 20 & 71,43 & 8 & 28,57 & 28 & 100 & \multirow{3}{*}{4,266} \\
\hline & $\leq 0,3 \mathrm{~mW} / \mathrm{cm}^{2}$ & 9 & 40,91 & 13 & 59,09 & 22 & 100 & \\
\hline \multicolumn{2}{|l|}{ Total } & 29 & 58 & 21 & 42 & $\mathbf{5 0}$ & 100 & \\
\hline
\end{tabular}

Table 3 Risk Factors Related with the Occurrence photokeratitis in welders of PT. PAL Indonesia (Persero) Surabaya, 2014

\begin{tabular}{|l|l|l|}
\hline & $\mathrm{B}$ & $\operatorname{Exp}(\mathrm{B})$ \\
\hline IPUV Category (1) & $-1,715$ & 0,180 \\
\hline Age Category (1) & $-1,962$ & 0,141 \\
\hline PKVA Category (1) & $-2,762$ & 0,063 \\
\hline KM Category (1) & $-2,556$ & 0,078 \\
\hline PPE Category (1) & $-3,379$ & 0,034 \\
\hline LP Category (1) & $-1,165$ & 0,205 \\
\hline Constant & 7,111 & 1225,062 \\
\hline
\end{tabular}

Table 3 shows the test logistic regression risk factors related with the occurrence of photokeratitis on the welder. Measurement of the intensity of UV exposure on respondents with great intensity of $0.3 \mathrm{~mW} / \mathrm{cm} 2$ at risk of $1 / 0.180=5.55$ times compared to respondents who are exposed to UV radiation intensity is less than $0.3 \mathrm{~mW} / \mathrm{cm} 2$. Respondents with more than 41 years of age at risk of photokeratitis occurrence by $1 / 0.141=7.09$ times compared with respondents aged less than 41 years.

Respondents who rarely consumed vitamin A greater risk photokeratitis $1 / 0.063=15.87$ times compared to that often consume vitamin A. Respondents who always had complaints of eye riskier $1 / 0.078=12.82$ times for the photokeratitis than never felt eye complaints. Respondents who sometimes use personal protective equipment is at risk of photokeratitis by $1 / 0.034=29.41$ times compared to the always receipts of personal protective equipment. Respondents with long exposure to more than 8 hours a risk of $1 / 0.205=4.87$ times compared to respondents who receipt less than 8 hours at work.

Overall variable in logistic regression is the most dominant risk factor for respondents to experience photokeratitis is the variable use of personal protective equipment with a value of 29.41 times compared with the other independent variables.

\section{DISCUSSION}

Limitations of this analysis does not include a variable period of employment in the logistic regression test for the variation of the variable period of employment is considered disturbing the greater the risk and the strong relationship of the other independent variables.

The results of statistical tests respondent characteristics include age, the pattern of consumption of vitamin A, eye complaints and use of PPE is stated to have a relationship with photokeratitis.

\section{a. Age}

With age, a point distant vision or furthest point that can be seen clearly also began to decrease or shorter. (Notoatmodjo, 2005). Thus the closer of the distance from the eye to the welding source or from field work, the penetrating power of ultraviolet light reaching the eye is also greater. This provides a strong influence on the cornea due to the radiation generated.

\section{b. The Pattern of Consumption of Vitamin A}

Vitamin A deficiency causes night blindness, serosis, and keratinization conjunctiva and cornea, which in turn lead to defects in the corneal epithelium (Arisman, 2004). Early signs of vitamin A deficiency among others eyes feel hot and itchy, cannot stand the light and sharpness loss of the eye.

The process of observation on the food provided by the company and a questionnaire about the pattern of vitamin A consumption found that the majority of respondents in one day not to consume four types of foods and supplements that contain vitamin $\mathrm{A}$. The reason not to consume food and supplements containing vitamin $\mathrm{A}$ in addition to not know what kind of foods containing vitamin A, they only consume food to satisfy the desire to eat them regardless of whether the food contains vitamin A or not.

Consumption of vitamin A which is less than workers weld can cause the cornea to be susceptible to keratinization, so the more the cornea absorbs ultraviolet radiation, would cause defects in the corneal epithelium or photokeratitis. 


\section{Eye Complaints}

Corneal epithelial damage will cause eye complaints such as sandy feeling with photophobia (glare) and tearing, corneal looked bleak that can cause vision disturbances, severe pain and blepharospasm.

The results of such research that complaints eyes feel gritty eyes, red eyes, swollen, opaque and others are presented in the questionnaire related to the occurrence of photokeratitis.

This is in line with research conducted Pitts (1974) are an individual experience eyes feel gritty sensation, swelling of the eyelids, photophobia, lacrimation and blurred vision or blurred.

To be able to tell if the welder is actually experiencing photokeratitis, besides Seeing Eye complaints of the welder is also performed fluorescein test. Fluorescein test results obtained from that 29 people had positive welder photokeratitis. Corneal epithelial defect location is at the inferior or lower part of the cornea. This is because when the eyes are exposed to light from welding, welder spontaneous wink so that the location of the defect is located on the bottom.

\section{d. Use of PPE}

Personal protective equipment should be provided in the welding is welding goggles, welding helmets and face shields are used welder to protect the eyes from exposure to UV radiation intensity, infrared rays and visible light. (Bintoro, 1999). Results of research conducted stating that there is a relationship between the uses of personal protective equipment with the photokeratitis. Type of welding that is often used is the SMAW and FCAW with strong use of different currents in these two welding. Measurements were carried out for strong currents SMAW welding type using powerful current of 220 amperes and strong FCAW welding current used by 300 Amperes.

Giving eye protective equipment provided should be tailored to the strong large currents used by welders. According to JIS T 8141-1970 regulations, to bow 220 A-300 A number of colors used are numbers 13 and 14 . However, the results of field observations and questionnaires showed that the provision of eye protection is not adjusted to the number of colors based on the transmission of strong electric currents used.

All eye protective equipment for welding different no good shape, type of transmission number and size. There is even a welder who did not know the number of colors on the eye protective equipment used. Conditions in welding helmets welding glass there were already scratched; its position is not close fully in order so that there is a loophole that allows the UV rays can penetrate. UV light emitted can also enter through the edge of personal protective equipment, because size does not fit snugly against the face so that it remains potentially exposed to UV light. The results of statistical tests for job characteristics that include length of service, duration of exposure and intensity of exposure to UV radiation, namely:

\section{A. Long Exposure}

Prolonged exposure to ultraviolet light intensity is directly proportional to the amount of radiation received by workers. (Darmawan, 1977). Most of the powers of welders who work more than 8 hours in one day with a lunch break for 1 hour. Work schedule specified in the general engineering division are Monday-Friday. However, if the project should be completed on time while a lot of obstacles in the field one late delivery of materials, make the welder had to work overtime and schedule changes are from Monday to Sunday with working hours even reached 11 hours. This resulted in the eyes of the welder is exposed to UV light with a constant frequency, while to restore the function of the cornea at least the eye to rest for 24-48 hours without contact with the welding equipment and sources of direct sunlight. (Ilyas, Yulianti, 2014).

These results also support the view that the frequency of exposure is more often made more UV radiation is able to get into the cornea and cause a reaction. In addition to the frequency the more frequent, corneal damage caused by previous exposure has not yet fully recovered following the next exposure, this resulted in disruption of corneal reemerge. (Olifhifski, 1985)

\section{B. Intensity Ultraviolet Radiation Exposure}

Direct UV measurement at 50 welder for 10 seconds was obtained for SMAW welding types, namely 0,568 $(\mathrm{mW} / \mathrm{cm} 2)-0.747(\mathrm{~mW} / \mathrm{cm} 2)$, while for the type of FCAW welding measurement results is 0.404 (mW/cm2)-0.754 $(\mathrm{mW} / \mathrm{cm} 2)$. The results of these measurements exceed NAB effective radiation exposure times per day for 10 seconds set by the Minister of Manpower and Transmigration No. Per.13 / MEN / X / 2011 of 2011 on the Threshold Limit Value Factor Physical and Chemical Factors in the Workplace is $0.3(\mathrm{~mW} / \mathrm{cm} 2)$.

UV radiation intensity values generated exceeds the exposure time per day during the welding process accumulating creating a risk of impaired eye health workers during work and causediscomfort. The high intensity of UV radiation received by the eyes of welders in this study is related to the occurrence of photokeratitis.

\section{CONCLUSION}

The most dominant risk factor for welding workers to experience photokeratitis is the variable use of personal protective equipment with a value of 29.41 compared with the other independent variables.

\section{SUGGESTION}

Feeding and supplement that contains vitamin A to prevent vitamin A deficiency and to reduce eye complaints are advised rest of the welder welding activities for 48 hours. 
The company in the provision of personal protective equipment especially eye protection equipment should pay attention to both right and should be given a double eye protector and welding helmets which have components automatically adjust the current strength and position welding helmet making it easier for the welder to work. Measurement of the intensity of the UV radiation is done periodically in order to know how much radiation intensity which exposes the welder that can be protective measures against the welder.

Periodic eye examinations for the welder performed by an ophthalmologist so that appropriate action can be performed for the treatment and welder are aged 40 and above are advised not too long contact with welding equipment.

\section{REFERENCES}

[1]. Arisman, (2004). Gizi dalam Daur Kehidupan: Buku Ajar Ilmu Gizi. Buku Kedokteran EGC: Jakarta.

[2]. Dharmawan, (1977). Referensi Visual Terapi Empirik Infeksi Bakteri. Jakarta: Elek Media Komputindo.

[3]. Notoatmodjo, Soekidjo. (2005): Pengantar Pendidikan Kesehatan dan Ilmu Perilaku Kesehatan. Yogyakarta: Andi Offset.

[4]. Olishifski, J.B. (1985). Fundamental of Industrial Hygiene ( $2^{\text {nd }}$ ed). Washington DC: National Safety Council

[5]. Pitts. (1974). The Human ultraviolet spectrum. Am J Optom Physiol Optics 51 (12)

[6]. Sidharta Ilyas, Sri Rahayu Yulianti, (2014). Ilmu Penyakit Mata (edisi kelima), Jakarta: Badan Penerbit FKUI [7]. Peraturan Menteri Tenaga Kerja dan Transmigrasi No. Per.03/MEN/1982 tentang Pelayanan Kesehatan Tenaga Kerja

[8]. Peraturan Menteri Tenaga Kerja dan Transmigrasi Nomor Per.13/MEN/X/2011 tahun 2011 tentang Nilai Ambang Batas Faktor Fisika dan Faktor Kimia di Tempat Kerja. 